\title{
Students' dietary habits, food service satisfaction, and attitude toward school meals enhance meal consumption in school food service
}

\author{
Kyung-Eun Lee \\ Major of Food \& Nutrition, Seoul Women's University, 621 Hwarangro, Nowon-gu, Seoul 01797, Korea
}

BACKGROUND/OBJECTIVES: This study aimed to compare student consumption of school meals by school level, to identify the influencing factors of school meal consumption, and to assess improvement needs of school food service among students. SUBJECTS/METHODS: A total of 1,441 elementary, middle, and high school students attending 58 schools in Gyeonggi-do, South Korea participated in the survey in 2015. A questionnaire and informed consent forms for students and legal guardians were sent home and completed responses were returned to the researcher.

RESULTS: Approximately $58 \%$ of the students perceived the portion sizes of school meals as appropriate and $76.1 \%$ consumed almost all or all of the meals served. More elementary and middle school students than high school students consumed almost all or all of the meals $(P<0.001)$. A regression analysis revealed that the students with a higher dietary behavior score $(P$ $<0.001)$, higher satisfaction with food service $(P<0.001)$, a higher environmental protection practice score $(P<0.05)$, and more positive attitudes toward school meals $(P<0.01)$ consumed significantly more meals. The provision of foods that taste good and reflecting student opinions on menus were the most important factors for increasing school meal consumption.

CONCLUSIONS: To increase consumption of school meals, food service staff should provide students with quality meals and engage students in school food service. Nutrition education that emphasizes healthy eating behaviors and cafeteria environment modification that applies strategies based on behavioral economics can encourage students to consume more school meals.

Nutrition Research and Practice 2019;13(6):555-563; https://doi.org/10.4162/nrp.2019.13.6.555; plSSN 1976-1457 elSSN 2005-6168

Keywords: Schools, food services, eating habits, satisfaction

\section{INTRODUCTION}

School food service provides students with nutritionally balanced meals to maintain their nutrition and health, to optimize physical and cognitive growth, and to develop good eating habits that may be carried through to adulthood [1]. In 2018, a total of 5.61 million Korean students participated in the school food service program in 11,818 schools nationwide [2]. Like other institutional food services, school food service receives diverse inputs from the environment and transforms them to produce desired outputs [3]. Major outputs of school food service are quality meals, student consumption, and satisfaction. During the transformation process, waste is also generated. While some plate waste is inevitable, significant waste is a sign that the food service system lacks communication with students [4].

Plate waste, which refers to the edible portion that is served to students but is uneaten, is a major food waste in school food service [5]. Not only is plate waste an indicator of inefficiency of the food service system but it is also a waste of nutrients that should have been consumed by the students [4]. An et al. [6] reported that approximately $10-20 \%$ of the nutrients served were discarded as plate waste at schools. In the US National School Lunch Program, 15\% of folate was discarded as a result of students not eating vegetables and fruits served [5]. Food service professionals are responsible for encouraging students to consume school meals as well as for providing nutritional meals.

According to the 2018 Student Health Examination of the Korea Ministry of Education, the obesity rate among students has reached $25 \%$, and students are not following the recommended dietary practices such as "drinking milk or dairy products every day" and "eating vegetables every day" [7]. Less than $30 \%$ of elementary, middle, and high school students consume vegetables every day. Low consumption of vegetables has also been found in school food service settings. Research findings show that student consumption rates are low for vegetables, seafoods, soups/stews, and kimchi in school food service $[8,9]$. It has been reported that students do not eat enough at school because the foods are not tasty, or the students are served large portions sizes or foods they do not like [8-10]. Improper scheduling of lunch time and availability of competitive foods at schools were also found to lower student consumption of school meals [4].

\footnotetext{
The study was supported by Gyeonggi Office of Education in 2015.

${ }^{\S}$ Corresponding Author: Kyung-Eun Lee, Tel. 82-2-970-5648, Email. Klee@swu.ac.kr

Received: September 9, 2019, Revised: September 19, 2019, Accepted: October 13, 2019

This is an Open Access article distributed under the terms of the Creative Commons Attribution Non-Commercial License (http://creativecommons.org/licenses/by-nc/3.0/) which permits unrestricted non-commercial use, distribution, and reproduction in any medium, provided the original work is properly cited.
} 
Nutrition education has been found to effectively change attitudes and promote healthy eating among students $[4,10,11]$. It has been suggested that nutrition education can have lasting effects when coordinated with food service activities such as the provision of high-quality foods and healthy food options, and tasting events $[4,11]$. Research revealed that students consume school meals more when they are satisfied with the food service [12,13]. Hong et al. [12] reported that elementary students are moderately satisfied with school food service and are more satisfied with the sanitation and menus than with the service. The students who consume more show significantly higher satisfaction scores. Kim et al. [13] reported that the amount of plate waste is negatively correlated with student food service satisfaction score; the more students are satisfied with school food service, the more food they consume.

When various factors influencing student consumption are identified and managed, positive effects can be expected such as lower cost, higher satisfaction, good dietary behaviors, and positive image of and trust in school food service. The aims of this study were to compare consumption of school meals and perceptions of school food service by school level, to investigate factors influencing the consumption of school meals from the view point of students, and to identify improvement needs of school food service among students.

\section{SUBJECTS AND METHODS}

\section{Study subjects}

The study population consisted of students attending primary and secondary schools in Gyeonggi-do, South Korea. One or two schools were randomly selected from 25 District Offices of Education in Gyeonggi-do, for a total of 112 schools (41 elementary schools, 36 middle schools, 35 high schools). Then one fifth-grade class from the elementary schools and one junior class from the middle and high schools were selected. Questionnaires were distributed to the students in their homeroom classes, and an envelope and informed consent forms for the students and their legal guardians were also distributed. The students returned completed responses to their homeroom teachers, and the teachers sent them to the researcher. The survey was conducted during November and December of 2015. A total of 1,441 students from 58 elementary, middle, and high schools responded. Approval for the study was obtained from Seoul Women's University Institutional Review Board (SWU IRB-2015A-26).

\section{Instrument development}

A survey instrument was developed based on a review of the literature related to student eating behaviors [14,15], consumption of the food provided by the school food service $[8,9,12,13]$, satisfaction with the school food service $[16,17]$, and attitudes toward the environment and environmental protection practices [18,19], and based on focus group interviews with students. The questionnaire consisted of four sections: dietary behaviors and consumption of school meals, satisfaction and improvement needs of the school food service, attitudes toward the environment and food and environmental protection practices, and demographic information.
Dietary behaviors were assessed with 11 items (e.g., "I eat various foods," and "I eat at least one vegetable dish each meal"), with responses based on a 5-point scale (from 1 ["never"] to 5 ["always"]). A dietary behavior score was calculated as the sum of the points of each item. A response for the consumption of school meals was based on a 5-point scale (from 1 ["eat all served"] to 5 ["eat none"]), and that for the perception of the portion served was also based on a 5-point scale (from 1 ["very small"] to 5 ["very large"]). Students who had less than half the portion served were asked about their reasons for eating less, and students who had half or more than half the portion served were asked about their reasons for eating more. Responses for satisfaction with food service were based on a 5-point scale (from 1 ["very dissatisfied"] to 5 ["very satisfied"]). The students were asked to rate the need to improve school food service (on a 5-point scale from 1 ["very unnecessary"] to 5 ["very necessary"]). They were also asked to rate their attitudes (on a 5-point scale from 1 ["strongly disagree"] to 5 ["strongly agree"]) toward food and environments and environmental protection practices (on a 5-point from 1 ["never"] to 5 ["always"]). Demographic information included gender, school level, eating location, and service type.

\section{Statistical analysis}

Descriptive statistics were obtained for all variables, and an one-way analysis of variance (ANOVA) and chi-square analysis were performed to compare differences by school level. When significant differences were found from the ANOVA, Duncan's post-hoc test was performed. A factor analysis was used to reduce the number of items on attitudes toward food and environment, and a regression analysis was used to identify variables that influenced meal consumption at school. Statistical significance was set at 0.05 . The statistical analysis was performed using SPSS version 23.0 (IBM Corporation, Armonk, NY, USA).

\section{RESULTS}

\section{Participant characteristics}

A total of 1,441 students participated in the survey, and $46.5 \%$ were boys. Among them, $43.0 \%$ were elementary school students, followed by middle school students (38.2\%) and high school students (24.8\%). Approximately $66.0 \%$ of the students had school meals in the cafeteria, and $34.0 \%$ had meals in classrooms. Meals were served by student volunteers $(38.7 \%)$, by student volunteers and food service staff $(37.0 \%)$, or by food service staff (17.3\%). Seven percent of the students responded they used self-service options.

Student perception of portion size and consumption of school meals

Fifty-eight percent of the students perceived the portion size of the school meals as appropriate and $23.8 \%$ perceived it as small (Table 1). Similarly, $76.1 \%$ of the students consumed almost all or all of the meals served, and $6.8 \%$ consumed less than half of the meals. The perception of the serving portion and amount consumed differed by student school level; $70.0 \%$ of the elementary school students perceived the serving portion as appropriate, whereas $41.7 \%$ of the high school students 
Table 1. Students perceptions of school meal portion sizes and consumed amounts by school leve

\begin{tabular}{|c|c|c|c|c|c|c|}
\hline Variable & & Total & $\begin{array}{c}\text { Elementary school } \\
\text { student }\end{array}$ & $\begin{array}{l}\text { Middle school } \\
\text { student }\end{array}$ & $\begin{array}{l}\text { High school } \\
\text { student }\end{array}$ & $P$-value \\
\hline \multirow[t]{6}{*}{ Served portion size } & Very small & $91(6.4)$ & $15(2.5)$ & $28(6.1)$ & $48(13.5)$ & $<0.001$ \\
\hline & Small & $340(23.8)$ & $84(13.8)$ & $154(33.4)$ & $100(28.2)$ & \\
\hline & Appropriate & $826(57.9)$ & $426(70.0)$ & $235(51.0)$ & $165(46.5)$ & \\
\hline & Large & $102(7.1)$ & $59(9.7)$ & $25(5.4)$ & $18(5.1)$ & \\
\hline & Very large & $13(0.9)$ & $8(1.3)$ & $3(0.7)$ & $2(0.6)$ & \\
\hline & Inconsistent & $55(3.9)$ & $17(2.8)$ & $16(3.5)$ & $22(6.2)$ & \\
\hline \multirow[t]{5}{*}{ Consumed amount } & Eat all served & $310(22.9)$ & $182(33.3)$ & $71(15.4)$ & 57 (16.6) & $<0.001$ \\
\hline & Eat almost all served & $719(53.2)$ & $262(48.0)$ & $261(56.7)$ & $195(56.7)$ & \\
\hline & Eat half the portion served & $230(17.0)$ & $77(14.1)$ & $85(18.5)$ & $68(19.8)$ & \\
\hline & Eat a little & $87(6.4)$ & $24(4.4)$ & $39(8.5)$ & $23(6.7)$ & \\
\hline & Eat none & $6(0.4)$ & $1(0.2)$ & $4(0.9)$ & $1(0.3)$ & \\
\hline
\end{tabular}

Data are frequency (\%).

Table 2. Reasons of eating and wasting school meals perceived by students

\begin{tabular}{|c|c|c|c|c|c|}
\hline Statement & Total & $\begin{array}{l}\text { Elementary school } \\
\text { student }\end{array}$ & $\begin{array}{l}\text { Middle school } \\
\text { student }\end{array}$ & $\begin{array}{l}\text { High school } \\
\text { student }\end{array}$ & $P$-value \\
\hline \multicolumn{6}{|l|}{ Reasons for eating half or more than half of the meals } \\
\hline Because the food tastes good. & $3.65 \pm 1.09$ & $3.97 \pm 1.02^{\mathrm{a}}$ & $3.50 \pm 1.02^{b}$ & $3.25 \pm 1.13^{c}$ & $<0.001$ \\
\hline Because the appropriate portion size for me is served. & $3.64 \pm 1.00$ & $3.91 \pm 0.96^{\mathrm{a}}$ & $3.46 \pm 0.94^{b}$ & $3.40 \pm 1.04^{b}$ & $<0.001$ \\
\hline Because eating whole meals is good for one's health. & $3.51 \pm 1.07$ & $3.92 \pm 1.00^{\mathrm{a}}$ & $3.32 \pm 0.99^{b}$ & $3.04 \pm 1.03^{c}$ & $<0.001$ \\
\hline Because serving portions are small. & $3.42 \pm 1.18$ & $3.47 \pm 1.28$ & $3.32 \pm 1.10$ & $3.45 \pm 1.10$ & 0.129 \\
\hline $\begin{array}{l}\text { Because I am concerned about the effects of food waste on } \\
\text { the environment. }\end{array}$ & $3.34 \pm 1.18$ & $3.62 \pm 1.19^{a}$ & $3.14 \pm 1.09^{b}$ & $3.08 \pm 1.19^{b}$ & $<0.001$ \\
\hline Because I do not want to dispose of foods. & $3.15 \pm 1.18$ & $3.22 \pm 1.22$ & $3.05 \pm 1.15$ & $3.18 \pm 1.16$ & 0.096 \\
\hline $\begin{array}{l}\text { Because the school has a campaign or event for food waste } \\
\text { reduction. }\end{array}$ & $2.29 \pm 1.23$ & $2.26 \pm 1.28$ & $2.25 \pm 1.11$ & $2.40 \pm 1.29$ & 0.186 \\
\hline Because teachers encourage me to eat all the food served. & $2.24 \pm 1.31$ & $2.52 \pm 1.46^{\mathrm{a}}$ & $2.07 \pm 1.11^{\mathrm{b}}$ & $1.95 \pm 1.15^{\mathrm{b}}$ & $<0.001$ \\
\hline \multicolumn{6}{|l|}{ Reasons for eating less than half of the meals } \\
\hline Because the food does not taste good. & $3.76 \pm 1.21$ & $3.00 \pm 1.19^{\mathrm{a}}$ & $3.98 \pm 1.11^{b}$ & $4.14 \pm 1.09^{b}$ & $<0.001$ \\
\hline Because items on the menu are not the preferred items. & $3.65 \pm 1.25$ & $2.96 \pm 1.26^{\mathrm{a}}$ & $4.12 \pm 0.84^{b}$ & $3.59 \pm 1.43^{b}$ & $<0.001$ \\
\hline Because I do not have appetite. & $2.68 \pm 1.33$ & $2.93 \pm 1.41$ & $2.73 \pm 1.30$ & $2.38 \pm 1.29$ & 0.290 \\
\hline Because the portion is too large. & $2.46 \pm 1.19$ & $2.96 \pm 1.37^{\mathrm{a}}$ & $2.39 \pm 1.00^{\mathrm{ab}}$ & $2.07 \pm 1.16^{b}$ & 0.017 \\
\hline Because eating time is short. & $2.16 \pm 1.26$ & $1.88 \pm 1.03$ & $2.24 \pm 1.30$ & $2.34 \pm 1.37$ & 0.364 \\
\hline Because I want to play with friends after eating meal. & $2.00 \pm 1.20$ & $2.46 \pm 1.35$ & $1.88 \pm 1.12$ & $1.76 \pm 1.09$ & 0.056 \\
\hline Because teachers allow me to leave food uneaten. & $1.90 \pm 1.10$ & $2.26 \pm 1.13$ & $1.85 \pm 1.15$ & $1.66 \pm 0.94$ & 0.111 \\
\hline Because I am on a diet. & $1.83 \pm 1.23$ & $1.85 \pm 1.43$ & $1.83 \pm 1.26$ & $1.83 \pm 1.00$ & 0.997 \\
\hline Because I want to study after eating meal. & $1.70 \pm 0.98$ & $1.70 \pm 0.82$ & $1.73 \pm 1.07$ & $1.69 \pm 1.00$ & 0.984 \\
\hline Because I participate in club activities during lunchtime. & $1.68 \pm 1.10$ & $1.58 \pm 1.02$ & $1.61 \pm 1.12$ & $1.90 \pm 1.18$ & 0.479 \\
\hline Because I have snacks before lunch. & $1.58 \pm 1.00$ & $1.33 \pm 0.73$ & $1.66 \pm 1.09$ & $1.72 \pm 1.10$ & 0.296 \\
\hline
\end{tabular}

Data are mean $\pm \mathrm{SD}$.

A 5-point Likert scale was used from 1 (strongly disagree) to 5 (strongly agree).

a,b,c Different superscripts in the same row mean significant difference by Duncan's post-hoc test at $P<0.05$.

perceived it as small or very small $(P<0.001)$. About $33 \%$ of the elementary school students consumed all meals, but only $15.4 \%$ of the middle school students and $16.6 \%$ of the high school students consumed all meals $(P<0.001)$

Causes of eating and wasting school meals

The students who consumed half or more than half the portion rated the following reasons highly: "because food tastes good" (3.65 points), "because the appropriate portion size for me is served" (3.64 points), and "because eating whole meals is good for one's health" (3.51 points) (Table 2). However, "because the school has a campaign or event for food waste reduction" (2.29 points) and "because teachers encourage me to eat all the food served" (2.24 points) received less than moderate ratings. When compared by school level, the elementary school students agreed significantly more with the statements "because the food tastes good," "because the appropriate portion size for me is served," "because eating whole meals is good for one's health," and "because I am concerned about the effects of food waste on the environment" than middle and high school students $(P<0.001)$. Student attitudes did not differ significantly by school level on the items 
"because serving portions are small," "because I do not want to dispose of foods," and "because the school has a campaign or event for food waste reduction."

The students who had less than half the portion served rated "because the food does not taste good" (3.76 points) and "because items on the menu are not the preferred items" (3.65 points) highly as reasons for eating less. On the other hand, other statements such as "because I have snacks before lunch," "because I participate in club activities during lunchtime," "because I am on a diet," and "because teachers allow me to leave food uneaten" were rated low. The reasons for eating less than half the portion differed by school level; middle and high school students rated "because the food does not taste good" and "because items on the menu are not the preferred items" higher than the elementary school students $(P<0.001)$. The elementary school students rated "because the portion is too large" higher than their high school counterparts $(P<0.05)$.

Food service satisfaction, dietary behaviors, attitudes toward food and the environment, and environmental protection behaviors

The average score for satisfaction with school food service was 3.60 points (Table 3). Elementary school students (3.97 points) were the most satisfied, followed by middle school students (3.41 points) and high school students (3.22 points) $(P<0.001)$. The students were highly satisfied with the nutrition
(3.83 points) and sanitation (3.80 points) of school meals but moderately satisfied with how well the meals met student requests (3.31 points).

The average dietary behavior score was 39.65 points (possible points: $0-55$ points), and the score differed significantly by school level $(P<0.001)$. Compared with the dietary behavior score of the elementary school students (42.01 points), those of the middle and high school students (39.77 points and 38.45 points, respectively) were significantly lower (Table 4). Factor analysis of attitudes toward the environment and food resulted in two separate factors: concerns about the environment and attitudes toward school meals. In terms of concerns about the environment, students perceived environmental protection (4.39 points), animal rights (4.38 points), and conservation of resources (4.38 points) to be highly important issues (Table 4 ). In terms of attitudes toward school meals, the students showed appreciation toward food service staff and were aware of the importance of balanced eating moderately. Generally elementary school students showed more positive attitudes than the middle and high school students.

Among the environmental protection behaviors, "discarding waste separately" (4.22 points) was rated the highest and "not using disposable products" (3.15 points) the lowest. "Not leaving food uneaten" was rated moderately. The practice level of environmental protection behaviors was lowered in order

Table 3. Student satisfaction with school food service

\begin{tabular}{|c|c|c|c|c|c|}
\hline Component & Total & $\begin{array}{c}\text { Elementary school } \\
\text { student }\end{array}$ & $\begin{array}{l}\text { Middle school } \\
\text { student }\end{array}$ & $\begin{array}{l}\text { High school } \\
\text { student }\end{array}$ & $P$-value \\
\hline Nutritional balance of meals & $3.83 \pm 0.99$ & $4.22 \pm 0.88^{\mathrm{a}}$ & $3.65 \pm 0.95^{b}$ & $3.40 \pm 0.98^{c}$ & $<0.001$ \\
\hline Sanitation of meals & $3.80 \pm 1.05$ & $4.14 \pm 0.99^{\mathrm{a}}$ & $3.56 \pm 1.02^{\mathrm{b}}$ & $3.54 \pm 1.01^{\mathrm{b}}$ & $<0.001$ \\
\hline Temperature of food served & $3.72 \pm 1.06$ & $4.09 \pm 0.97^{\mathrm{a}}$ & $3.52 \pm 1.02^{b}$ & $3.32 \pm 1.05^{c}$ & $<0.001$ \\
\hline Sanitation of tableware/utensils & $3.67 \pm 1.06$ & $3.92 \pm 1.06^{\mathrm{a}}$ & $3.54 \pm 0.99^{b}$ & $3.41 \pm 1.04^{b}$ & $<0.001$ \\
\hline Friendly food service staff & $3.65 \pm 1.16$ & $3.92 \pm 1.17^{\mathrm{a}}$ & $3.51 \pm 1.02^{b}$ & $3.36 \pm 1.22^{c}$ & $<0.001$ \\
\hline Food presentation & $3.64 \pm 1.07$ & $3.92 \pm 1.06^{\mathrm{a}}$ & $3.52 \pm 1.03^{b}$ & $3.32 \pm 1.01^{c}$ & $<0.001$ \\
\hline Taste of food & $3.63 \pm 1.14$ & $4.07 \pm 0.98^{\mathrm{a}}$ & $3.42 \pm 1.09^{b}$ & $3.14 \pm 1.17^{c}$ & $<0.001$ \\
\hline Dining environment & $3.61 \pm 1.09$ & $3.92 \pm 1.08^{\mathrm{a}}$ & $3.43 \pm 1.03^{b}$ & $3.31 \pm 1.07^{b}$ & $<0.001$ \\
\hline Variety of menus & $3.56 \pm 1.17$ & $4.03 \pm 1.03^{a}$ & $3.41 \pm 1.08^{b}$ & $2.95 \pm 1.18^{c}$ & $<0.001$ \\
\hline Portion size & $3.43 \pm 1.16$ & $3.86 \pm 1.06^{\mathrm{a}}$ & $3.23 \pm 1.06^{b}$ & $2.92 \pm 1.19^{c}$ & $<0.001$ \\
\hline Waiting time for service & $3.39 \pm 1.17$ & $3.78 \pm 1.11^{\mathrm{a}}$ & $3.07 \pm 1.12^{b}$ & $3.12 \pm 1.14^{b}$ & $<0.001$ \\
\hline Reflecting student opinions & $3.31 \pm 1.23$ & $3.77 \pm 1.15^{\mathrm{a}}$ & $3.05 \pm 1.12^{b}$ & $2.84 \pm 1.23^{c}$ & $<0.001$ \\
\hline Mean & $3.60 \pm 0.88$ & $3.97 \pm 0.79^{\mathrm{a}}$ & $3.41 \pm 0.81^{b}$ & $3.22 \pm 0.85^{c}$ & $<0.001$ \\
\hline
\end{tabular}

Data are mean $\pm \mathrm{SD}$.

A 5-point scale was used from 1 (very dissatisfied) to 5 (very satisfied).

${ }_{a, b, c}$ Different superscripts in the same row mean significant difference by Duncan's post-hoc test at $P<0.05$.

Table 4. Students' dietary behaviors, attitudes toward school meals and the environment, and environmental protection behaviors

\begin{tabular}{|c|c|c|c|c|c|}
\hline Statement & Total & $\begin{array}{l}\text { Elementary school } \\
\text { student }\end{array}$ & $\begin{array}{l}\text { Middle school } \\
\text { student }\end{array}$ & $\begin{array}{l}\text { High school } \\
\text { student }\end{array}$ & $P$-value \\
\hline Dietary behaviors ${ }^{1)}$ & $39.65 \pm 6.54$ & $42.01 \pm 6.48^{\mathrm{a}}$ & $39.77 \pm 5.94^{\mathrm{b}}$ & $38.45 \pm 6.14^{c}$ & $<0.001$ \\
\hline \multicolumn{6}{|l|}{ Concerns about the environment ${ }^{2)}$} \\
\hline It is important to protect the environment. & $4.39 \pm 0.78$ & $4.54 \pm 0.72^{\mathrm{a}}$ & $4.28 \pm 0.81^{b}$ & $4.25 \pm 0.81^{\mathrm{b}}$ & $<0.001$ \\
\hline $\begin{array}{l}\text { If people keep behaving like they do now, the Earth's } \\
\text { resources will be depleted. }\end{array}$ & $4.38 \pm 0.79$ & $4.48 \pm 0.79^{a}$ & $4.31 \pm 0.78^{b}$ & $4.28 \pm 0.82^{b}$ & $<0.001$ \\
\hline Animals have the same right to life as people in nature & $4.38 \pm 0.79$ & $4.48 \pm 0.79^{\mathrm{a}}$ & $4.31 \pm 0.78^{b}$ & $4.28 \pm 0.82^{b}$ & $<0.001$ \\
\hline $\begin{array}{l}\text { The government should enact stricter regulations to protect } \\
\text { the environment. }\end{array}$ & $4.09 \pm 0.88$ & $4.16 \pm 0.89^{\mathrm{a}}$ & $4.08 \pm 0.87^{\mathrm{ab}}$ & $4.00 \pm 0.87^{\mathrm{b}}$ & 0.021 \\
\hline Mean & $4.30 \pm 0.67$ & $4.41 \pm 0.63^{\mathrm{a}}$ & $4.24 \pm 0.70^{b}$ & $4.20 \pm 0.68^{b}$ & $<0.001$ \\
\hline
\end{tabular}


Table 4. continued

\begin{tabular}{|c|c|c|c|c|c|}
\hline Statement & Total & $\begin{array}{c}\text { Elementary school } \\
\text { student }\end{array}$ & $\begin{array}{l}\text { Middle school } \\
\text { student }\end{array}$ & $\begin{array}{l}\text { High school } \\
\text { student }\end{array}$ & $P$-value \\
\hline \multicolumn{6}{|l|}{ Attitudes toward school meals ${ }^{2}$} \\
\hline I feel grateful to my nutritionist and cooks. & $3.91 \pm 0.99$ & $4.12 \pm 0.93^{\mathrm{a}}$ & $3.83 \pm 0.96^{\mathrm{b}}$ & $3.67 \pm 1.07^{c}$ & $<0.001$ \\
\hline $\begin{array}{l}\text { I should try to eat various foods for good health, even } \\
\text { though I do not like them. }\end{array}$ & $3.79 \pm 1.02$ & $4.03 \pm 0.96^{\mathrm{a}}$ & $3.68 \pm 1.01^{b}$ & $3.51 \pm 1.04^{c}$ & $<0.001$ \\
\hline $\begin{array}{l}\text { I feel uncomfortable when I leave food uneaten at } \\
\text { school. }\end{array}$ & $3.42 \pm 1.16$ & $3.45 \pm 1.15$ & $3.46 \pm 1.15$ & $3.31 \pm 1.17$ & 0.122 \\
\hline $\begin{array}{l}\text { I'm worried about my friend's health, who doesn't eat } \\
\text { balanced meals. }\end{array}$ & $3.36 \pm 1.17$ & $3.42 \pm 1.17$ & $3.37 \pm 1.12$ & $3.26 \pm 1.22$ & 0.104 \\
\hline Mean & $3.62 \pm 0.86$ & $3.76 \pm 0.81^{\mathrm{a}}$ & $3.59 \pm 0.87^{b}$ & $3.44 \pm 0.90^{c}$ & $<0.001$ \\
\hline \multicolumn{6}{|l|}{ Environmental protection behaviors ${ }^{3)}$} \\
\hline I discard waste separately by type. & $4.22 \pm 0.95$ & $4.27 \pm 0.95$ & $4.20 \pm 0.95$ & $4.15 \pm 0.93$ & 0.136 \\
\hline I use a cup when brushing my teeth. & $3.41 \pm 1.28$ & $3.63 \pm 1.20^{\mathrm{a}}$ & $3.31 \pm 1.33^{b}$ & $3.17 \pm 1.31^{b}$ & $<0.001$ \\
\hline I turn off the power of electric machines after use. & $3.85 \pm 1.05$ & $3.88 \pm 1.08$ & $3.85 \pm 1.00$ & $3.79 \pm 1.06$ & 0.432 \\
\hline I do not leave food uneaten. & $3.60 \pm 1.07$ & $3.75 \pm 1.08^{\mathrm{a}}$ & $3.50 \pm 1.03^{b}$ & $3.46 \pm 1.06^{\mathrm{b}}$ & $<0.001$ \\
\hline I do not use disposable products. & $3.15 \pm 0.97$ & $3.25 \pm 0.99^{\mathrm{a}}$ & $3.14 \pm 0.99^{b}$ & $2.97 \pm 0.89^{b}$ & $<0.001$ \\
\hline Mean & $3.64 \pm 0.68$ & $3.76 \pm 0.37^{\mathrm{a}}$ & $3.60 \pm 0.69^{b}$ & $3.51 \pm 0.63^{c}$ & $<0.001$ \\
\hline
\end{tabular}

Data are mean $\pm \mathrm{SD}$.

1) The score was calculated from 11 dietary habits and was possible from 0 to 55 points.

2) A 5-point scale was used from 1 (strongly disagree) to 5 (strongly agree)

${ }^{3)}$ A 5-point scale was used from 1 (never) to 5 (always).

a,b,c Different superscripts in the same row mean significant difference by Duncan's post-hoc test at $P<0.05$.

Table 5. Regression explaining food consumption at school

\begin{tabular}{lcr}
\hline \multicolumn{1}{c}{ Variable } & Unstandardized B & Standardized $\beta$ \\
\hline Concern for the environment & -2.327 & -0.076 \\
Attitudes toward school meals & 2.273 & 0.094 \\
Environmental protection behaviors & 2.137 & 0.012 \\
Satisfaction with school food service & 0.003 & 0.069 \\
Dietary habits & 0.020 & 0.273 \\
\hline
\end{tabular}

Dependent variable: consumed amount of school meals

Adjusted $R^{2}=0.16(P<0.001)$

Table 6. Student improvement needs regarding school food service for increasing consumption

\begin{tabular}{|c|c|c|c|c|c|}
\hline Statement & Total & $\begin{array}{c}\text { Elementary school } \\
\text { student }\end{array}$ & $\begin{array}{c}\text { Middle school } \\
\text { student }\end{array}$ & $\begin{array}{l}\text { High school } \\
\text { student }\end{array}$ & $P$-value \\
\hline Serving food that students prefer & $4.18 \pm 0.92$ & $4.11 \pm 0.96^{\mathrm{a}}$ & $4.21 \pm 0.87^{\mathrm{ab}}$ & $4.29 \pm 0.89^{b}$ & 0.009 \\
\hline Pleasant cafeteria room temperature & $4.05 \pm 1.01$ & $3.99 \pm 1.07$ & $4.13 \pm 0.96$ & $4.00 \pm 1.02$ & 0.151 \\
\hline Reflecting student opinions on menus & $3.98 \pm 1.00$ & $3.84 \pm 1.08^{a}$ & $4.03 \pm 0.91^{\mathrm{b}}$ & $4.15 \pm 0.93^{b}$ & $<0.001$ \\
\hline Serving foods that are popular & $3.72 \pm 1.00$ & $3.61 \pm 1.00^{\mathrm{a}}$ & $3.81 \pm 0.97^{b}$ & $3.79 \pm 1.01^{b}$ & 0.002 \\
\hline Plating amount that I can consume & $3.70 \pm 1.23$ & $3.79 \pm 1.26^{b}$ & $3.67 \pm 1.21^{\mathrm{ab}}$ & $3.60 \pm 1.20^{\mathrm{a}}$ & 0.050 \\
\hline Students' understanding of proper portion size & $3.70 \pm 1.06$ & $3.88 \pm 1.03^{b}$ & $3.58 \pm 1.04^{\mathrm{a}}$ & $3.53 \pm 1.09^{a}$ & $<0.001$ \\
\hline Ensuring enough eating time & $3.67 \pm 1.13$ & $3.71 \pm 1.16$ & $3.67 \pm 1.09$ & $3.60 \pm 1.13$ & 0.368 \\
\hline Cafeteria with pleasant and bright light & $3.64 \pm 1.12$ & $3.75 \pm 1.23$ & $3.68 \pm 1.11$ & $3.55 \pm 1.05$ & 0.110 \\
\hline Awarding students or classes with no plate waste & $3.57 \pm 1.29$ & $3.65 \pm 1.33^{b}$ & $3.42 \pm 1.28^{\mathrm{a}}$ & $3.65 \pm 1.22^{\mathrm{b}}$ & 0.006 \\
\hline Providing nutrition information on menus & $3.53 \pm 1.09$ & $3.65 \pm 1.15^{\mathrm{b}}$ & $3.52 \pm 0.99^{b}$ & $3.35 \pm 1.10^{\mathrm{a}}$ & $<0.001$ \\
\hline Allowing students to select their food & $3.29 \pm 1.31$ & $2.93 \pm 1.41^{\mathrm{a}}$ & $3.55 \pm 1.16^{b}$ & $3.60 \pm 1.12^{b}$ & $<0.001$ \\
\hline Cafeteria environment without incessant noise & $3.25 \pm 1.24$ & $3.49 \pm 1.34^{\mathrm{b}}$ & $3.26 \pm 1.25^{\mathrm{a}}$ & $3.12 \pm 1.16^{\mathrm{a}}$ & 0.003 \\
\hline Implementing campaigns or events for plate waste reduction & $3.23 \pm 1.24$ & $3.27 \pm 1.28$ & $3.14 \pm 1.179$ & $3.26 \pm 1.26$ & 0.162 \\
\hline Providing information on food and menus & $2.94 \pm 1.22$ & $3.15 \pm 1.21^{\mathrm{c}}$ & $2.89 \pm 1.19^{b}$ & $2.62 \pm 1.22^{\mathrm{a}}$ & $<0.001$ \\
\hline Teacher supervision during mealtime & $2.90 \pm 1.26$ & $3.18 \pm 1.29^{c}$ & $2.79 \pm 1.20^{b}$ & $2.55 \pm 1.18^{a}$ & $<0.001$ \\
\hline Serving food on a neat dish & $2.70 \pm 1.30$ & $2.64 \pm 1.32$ & $2.80 \pm 1.29$ & $2.69 \pm 1.26$ & 0.136 \\
\hline
\end{tabular}

Data are mean $\pm \mathrm{SD}$

A 5-point scale was used from 1 (very unnecessary) to 5 (very necessary).

${ }^{a, b, c}$ Different superscripts in the same row mean significant difference by Duncan's post-hoc test at $P<0.05$. 
of elementary, middle, and high school. In particular, elementary school students showed a significantly higher level of practice than middle and high school students in using a cup for tooth brushing, not using disposable products, and not leaving food.

\section{Factors impacting student school meal consumption}

A regression analysis was performed to identify factors influencing student meal consumption at school (Table 5). The dependent variable was meal consumption at school and the independent variables were food service satisfaction, dietary behaviors, attitudes toward food and the environment, and environmental protection behaviors. The results showed that all the independent variables were significant predictors of meal consumption (adjusted $R^{2}=0.16, P<0.001$ ). The students with higher dietary behavior scores $(P<0.001)$, higher satisfaction with food service $(P<0.001)$, higher environmental protection behavior scores $(P<0.05)$, and more positive attitudes toward school meals $(P<0.01)$, consumed significantly more meals. On the other hand, environmental concerns showed a negative relationship $(P<0.05)$ with food intake.

\section{Student needs regarding school food service improvement}

With regard to methods of improving school food service, "serving food that students prefer" (4.18 points) and "pleasant cafeteria room temperature" (4.05 points) were rated the most highly by the students (Table 6). In contrast, "serving food on a neat dish" (2.70 points), "teacher supervision at mealtime" (2.90 points), and "the provision of information on food and menus" (2.94 points) received less than moderate ratings.

Comparing student needs regarding school food service improvement by school level, middle and high school students showed significantly higher demand, such as providing trendy menus $(P<0.01)$, offering selective menus $(P<0.001)$, and reflecting student opinions on the menu $(P<0.001)$ than elementary school students. Compared with middle and high school students, elementary school students were significantly more demanding with regard to teacher supervision during mealtime $(P<0.001)$, nutrition information on school menus $(P<0.001)$, provision of information on food and menus $(P<$ $0.01)$, and a quiet dining environment $(P<0.01)$.

\section{DISCUSSION}

This study aimed to compare student consumption and perceptions of school food service by school level, to investigate factors affecting meal consumption, and to identify improvement needs of school food service among students. Therefore 1,441 elementary, middle, and high school students were surveyed in Gyeonggi-do. Overall, elementary school students perceived serving portions as appropriate, but about $40 \%$ of the middle and high school students perceived them as small or very small. Contrary to their perception of the portions, $27 \%$ of the middle and high school students consumed half or less than half of the meals served. Student perception of portion sizes seemed to be inconsistent with their consumption. A study examining student consumption of school meals using an aggregate selective plate waste measurement for 5 days revealed that students consumed an average of $78 \%$ of the served meals
[20]. The consumption rate of elementary school students was $82.2 \%$, which was significantly higher than those of middle school students (71.8\%). By weighing serving portions and plate waste at elementary schools, An et al. [6] found that school menus provided adequate nutrients for students but approximately $10-20 \%$ of the nutrients served were discarded as plate waste.

When the students who consumed less than half of the school meals were asked about their reasons, "because the food does not taste good" and "because items on the menu are not the preferred items" were the most highly rated reasons. The reasons for consuming less than half differed significantly by school level. Elementary school students left meals behind because of big portion sizes, but middle and high school students left meals behind because they did not like the menus or the taste of the food. On the other hand, delicious food, appropriate portion sizes, and student understanding of portion sizes were the major reasons for students eating half or more than half of their school meals. Food waste reduction campaigns and events and teacher supervision did not seem to be effective in encouraging them to eat more, especially among middle and high school students. It is interesting that both students who consumed less than half and more than half of the school meals attributed their consumption rate to food taste. Story [21] emphasized that improving the palatability of food should be a priority in the effort to improve student consumption at school. Nutrition teachers and dietitians need to understand student food preferences and appetites and prioritize the improvement of food quality. To improve student consumption of vegetables and seafood, in particular, recipes can be modified [6]. To improve food quality, systematic quality control is needed, in which quality standards are established for each menu and consistent quality is maintained.

A lack of food preparation skills among food service staff was reported to be one of the barriers to providing healthier foods [22]. Nutrition intervention programs that use professional chefs to improve food quality have been found to be effective in increasing student vegetable consumption [23]. In the Chef Initiative, a nutrition pilot program, a professional chef trained cafeteria staff to prepare healthier lunches featuring more whole grains; fresh/frozen fruits and vegetables; and foods with less saturated fats, trans fats, and sugar. The students in schools that participated in the Chef Initiative were found to consume 0.36 more servings of vegetables per day than those in the control schools [23].

Large portion sizes was one of the reasons why students left meals behind. Therefore, service styles should be more flexible to accommodate student appetites and nutritional needs. Nutrition teachers and dietitians also need to reevaluate portions when significant plate waste is generated. Considering that students consumed more than half of their meals when they thought that the portion size was appropriate for them, nutrition education that includes information on proper portion sizes and conveys the importance of a balanced diet will help them to consume enough food.

This study found that food service satisfaction, dietary behaviors, attitudes toward school meals, and environmental protection behaviors were factors that increased consumption 
among primary and secondary school children. Kim et al. [13] reported a positive correlation between consumption and satisfaction with school food service, and Hong et al. [12] also found that student groups without plate waste showed higher satisfaction than their counterparts. Nutrition teachers and dietitians at schools should focus on improving satisfaction rather than simply forcing students to eat foods served, and conducting a waste reduction campaign. Since dietary behaviors were a significant predictor of meal consumption, nutrition education that emphasizes healthy eating behaviors should be carried out continuously.

In this study, environmental concerns were negatively correlated with meal intake. This finding indicates that students lack awareness of food waste treatment after disposal and its impact on the environment. Choi et al. [24] reported that middle school students knew that food waste was the cause of environmental pollution; however, they only made moderate efforts to reduce food waste to protect the environment. Park et al. [25] reported a similar trend in university students. After nutrition education on environmental protection related to plate waste reduction and healthy eating behaviors, plate waste decreased and eating behaviors and awareness of the environment improved significantly in elementary school students [10]. This finding suggests that nutrition education, which aims to increase student intake and to reduce plate waste, should include an effect of diets on health and the environment.

With regard to improving school food service, students showed high demands for delicious meals (4.18 point), pleasant cafeteria temperatures (4.05 point), and having their opinions considered in planning menus (3.98 point). The item on pleasant room temperature seemed to gain a high score because the survey was conducted during the months of November and December. Involving students in the school food service program also helps to increase student consumption and improve satisfaction [4]. Students can provide ideas and opinions, making menus more acceptable to fellow students. Student demand for neat tableware instead of the current portioned trays was low. They seemed to have the fixed idea that school meals were supposed to be served on stainless steel trays, even though serving and eating some soups/stews, noodles, and bibimbap using these trays can be awkward. One study found that attractive signage and appealing containers for fruits and vegetables increased selection and consumption in a school cafeteria [26].

In this study, student needs with regard to having enough eating time was rated as above moderate ( 3.67 point). Currently there is no standard or guideline for the length of the lunch period. Literature, however, has shown that time constraint was one factor prohibiting students from eating enough at school and that students ate less when meal time was scheduled when they were not hungry or the time to eat lunch was not sufficient [4]. Cohen et al. [27] reported that students at schools with mealtime of less than 20 minutes ate entrées 13\% less, milk $10 \%$ less, and vegetables $12 \%$ less than those with mealtime durations of more than 25 minutes. Elementary school students were found to consume significantly more meals when recess was scheduled before lunch than when recess was scheduled after lunch [28]. School policies should ensure that students consume enough food during lunchtime.

The need for selective menus had a moderate rating (3.29 point). Strategies that give students choices have been implemented to improve consumption [29]. The "Offer versus Serve" (OVS) method has been used to provide students with choices and reduce waste in the United States. This method requires that students choose from at least three of the five menu groups, which is a requirement for a reimbursable meal. Goggans et al. [30] compared student vegetable and fruit menu selection and intake in serve-only schools and OVS schools. Plate waste was significantly lower in OVS schools than in serve-only schools, but fruits and vegetable consumption did not differ significantly. The result implies that self-service and selective menus are not enough for promoting healthy eating, and they should be accompanied by other strategies that lead to desired behaviors.

In recent school-based nutrition interventions that encourage selection and consumption of healthier foods, choice architecture strategies have gained attention. These strategies modify the food environment and nudge students toward healthier choices [31]. The Smarter Lunchrooms Movement, which applies evidence grounded in behavioral economics, marketing, and psychology to the promotion of healthy eating behaviors at school, has annual fruit and vegetable tasting events, and it is recommended to increase vegetables and fruits intake [32]. In addition, to encourage students to select and consume healthy foods, the Smarter Lunchrooms Scorecard [32] lists simple and low-cost strategies, such as providing choices by serving at least two kinds of fruits and vegetables, offering sliced or cut fruits, and displaying a variety of mixed whole fruits in attractive bowls or baskets. Adams et al. [33] reported that the presence of salad bars did not increase fruits and vegetable consumption, but the variety of fruits and vegetables at salad bars was related to increased consumption in elementary schools. Middle school students selected fruits and vegetables 4 times more and consumed 3.4 times more food from salad bars inside serving lines than from salad bars outside lines [34]

This study identified the facilitators and barriers to eating school meals and revealed the improvement needs of school food service from the perspective of the students. The results also showed that students consumption can be enhanced by improving their dietary behaviors, attitudes toward school meals, and food service satisfaction. To improve school food service, food service staff should provide students with quality meals and involve them in the process. In the future, various strategies based on behavioral economics need to be applied to school food service and tested for their effectiveness in promoting healthy eating. Smith et al. [35] suggested that a marketing strategy should be applied together with nutrition education for students to select vegetables on their own and to improve their consumption of school meals. Nutrition education becomes more effective when coordinated with school meals and food service activities [4], and also can include topics on the relations among health, food, and the environment. A school community should understand that school lunchtime is a hands-on training session to practice the knowledge learned from nutrition education and should collaborate to make the school environment, including the cafeteria, healthier. 


\section{ACKNOWLEDGMENT}

The author appreciate Dr. Kyungjoo Kim, Dr. Chang-Hee Yoo, and Ji-Yeon Choi for their inputs in data collection and analysis.

\section{CONFLICT OF INTEREST}

The author declares no potential conflicts of interests.

\section{ORCID}

Kyung-Eun Lee: https://orcid.org/0000-0002-5821-578X

\section{REFERENCES}

1. Kwak TK, Ryu ES, Lee HS, Ryu K, Choi SK, Hong WS, Jang M, Moon HK, Chang HJ, Choi EH, Lee KE, Choi JH, Yi NY. Institutional Foodservice Operations. Seoul: Shinkwang Publishing Co.; 2016. p.18.

2. Ministry of Education. 2018 school food service statistics [Internet]. Sejong: Ministry of Education; 2019 [cited 2019 September 2]. Available from: https://www.moe.go.kr.

3. Kwak TK, Ryu ES, Lee HS, Hong WS, Chang HJ, Choi JH, Yi NY Foodservice Management. Seoul: Shinkwang Publishing Co.; 2014. p.58-60.

4. Guthrie JF, Buzby JC. Several strategies may lower plate waste in school feeding programs. Food Rev 2002;25:36-42.

5. Kim SH, Kwak TK, Choi EH, Lee KE. Food waste management practices and influencing factors at elementary school food services. Korean J Community Nutr 2007;12:815-25.

6. An JY, Lee HS. Assessment of the nutritional value of the plate waste generated in school foodservices in Kyungbuk area. J Korean Diet Assoc 2002;8:311-7.

7. Ministry of Education. Student health examination statistics [Internet]. Sejong: Ministry of Education; 2019 [cited 2019 September 1]. Available from: https://www.moe.go.kr/boardCnts/view.do?boardID $=294 \&$ boardSeq $=77144 \& \mathrm{lev}=0 \&$ searchType $=$ null\&statusYN=W\&pag $\mathrm{e}=1 \& \mathrm{~s}=\mathrm{moe} \& \mathrm{~m}=020402 \&$ opType $=\mathrm{N}$.

8. Yoon SJ, Kim HA. Elementary school students' perception of food waste and factors affecting plate waste rate of school foodservice in the Gyeongnam area. J Korean Diet Assoc 2012;18:126-40.

9. Kim MS, Jeon ER, Hwang KH, Jung LH. Perception and attitudes to leftover food at school food service - the elementary school students in Gwangju area. J Korean Soc Food Sci Nutr 2011;40: 137-41.

10. Kim SH, Choi EH, Lee KE, Kwak TK. Effects of nutrition education on food waste reduction. J Korean Diet Assoc 2007;13:357-67.

11. Hayes D, Contento IR, Weekly C. Position of the Academy of Nutrition and Dietetics, Society for Nutrition Education and Behavior, and School Nutrition Association: comprehensive nutrition programs and services in schools. J Nutr Educ Behav 2018;50:433-439.e1.

12. Hong WS, Chang HJ. The relationship between food service satisfaction and plate wastes in elementary school students. Korean J Soc Food Cookery Sci 2003;19:390-5.

13. Kim J, Ko SH, Kim HY. A study on plate waste and nutrient intake of school lunches in elementary school. Korean J Diet Cult 2000;15:29-40.

14. Ko SY, Kim KW. Nutrition label use, self-efficacy, snacking and eating behavior of middle school students in Kyunggi area. Korean J Community Nutr 2010;15:513-24.

15. Na SY, Ko SY, Um SH, Kim KW. Intakes and beliefs of vegetables and fruits, self-efficacy, nutrition knowledge, eating behavior of elementary school students in Kyunggi area. Korean J Community Nutr 2010;15:329-41.

16. Yi BS, Yang IS, Park MK. Annual analysis on quality attributes and customer satisfaction in school foodservice. Korean J Nutr 2009; 42:770-83.

17. Lee KA, Lyu ES. Comparison of student satisfaction with foodservice of middle school by place for meal service in Busan area. J Korean Soc Food Sci Nutr 2015;34:209-18.

18. Park CB, Back NG. A study on environmental awareness of elementary school students. J Environ Sci 2011;20:631-8.

19. Huh JR, Choi KH, Park SS. The change of elementary school student's awareness on the environment after ecological education programs. Korean Soc Environ Edu 2011;24:12-25.

20. Moon HK, Park MS, Lee KH. Nutrition management examined by plate waste measurement: a comparison with elementary schools and middle schools in the Changwon area. Korean J Community Nutr 2008;13:879-89.

21. Story M. The third School Nutrition Dietary Assessment Study: findings and policy implications for improving the health of US children. J Am Diet Assoc 2009;109:S7-13.

22. Cho $\mathrm{H}$, Nadow MZ. Understanding barriers to implementing quality lunch and nutrition education. J Community Health 2004;29:421-35.

23. Cohen JF, Smit LA, Parker E, Austin SB, Frazier AL, Economos CD, Rimm EB. Long-term impact of a chef on school lunch consumption: findings from a 2-year pilot study in Boston middle schools. J Acad Nutr Diet 2012;112:927-33.

24. Choi MY, Han MJ. An attitude about reduction of environmental pollution and school lunch leftovers in middle school students. Korean J Food Cult 2009;24:164-71.

25. Park SW, Shin EM. A survey on the awareness for the reduction of food waste by the use of university cafeteria. Korean J Food Nutr 2006;19:91-102.

26. Hanks AS, Just DR, Wansink B. Smarter lunchrooms can address new school lunchroom guidelines and childhood obesity. J Pediatr 2013;162:867-9.

27. Cohen JF, Jahn JL, Richardson S, Cluggish SA, Parker E, Rimm EB. Amount of time to eat lunch is associated with children's selection and consumption of school meal entrée, fruits, vegetables, and milk. J Acad Nutr Diet 2016;116:123-8.

28. Bergman EA, Buergel NS, Englund TF, Femrite A. The relationship of meal and recess schedules to plate waste in elementary schools. J Child Nutr Manag 2004;28.

29. Buzby JC, Guthrie JF. Plate waste in school nutrition programs: final report to Congress [Internet]. Washington, D.C.: Economic Research Service, USDA; 2002 [cited 2019 September 2]. Available from: https://naldc.nal.usda.gov/catalog/48204

30. Goggans MH, Lamber L, Chang Y. Offer versus serve or serve only: does service method affect elementary children's fruit and vegetable consumption? J Child Nutr Manag 2011;35.

31. Cohen JF, Richardson SA, Cluggish SA, Parker E, Catalano PJ, Rimm EB. Effects of choice architecture and chef-enhanced meals on the selection and consumption of healthier school foods: a randomized clinical trial. JAMA Pediatr 2015;169:431-7.

32. Cornell University. Smarter Lunchrooms Scorecard [Internet]. Ithaca 
(NY): Cornell University; 2019 [cited 2019 September 2]. Available from: https://www.smarterlunchrooms.org.

33. Adams MA, Pelletier RL, Zive MM, Sallis JF. Salad bars and fruit and vegetable consumption in elementary schools: a plate waste study. J Am Diet Assoc 2005;105:1789-92.

34. Adams MA, Bruening M, Ohri-Vachaspati $P$, Hurley JC. Location of school lunch salad bars and fruits and vegetable consumption in middle schools: a cross-sectional plate waste study. J Acad Nutr Diet 2016;116:407-16.

35. Smith SL, Cunningham-Sabo L. Food choice, plate waste and nutrient intake of elementary- and middle-school students participating in the US National School Lunch Program. Public Health Nutr 2014;17: 1255-63. 